\title{
European $\mathbf{X}$ tramile $\mathbf{C e n t r e}$ of $\mathbf{A}$ frican $\mathbf{S}$ tudies (EXCAS)
}

\section{EXCAS Working Paper}

\author{
WP/20/024
}

\section{Governance and the Capital Flight Trap in Africa 1}

Forthcoming: Transnational Corporations Review

Simplice A. Asongu

African Governance and Development Institute,

P. O. Box 8413, Yaoundé, Cameroon

E-mails: asongusimplice@yahoo.com asongus@afridev.org /

\section{Joseph Nnanna}

The Development Bank of Nigeria,

The Clan Place, Plot 1386A Tigris Crescent,

Maitama, Abuja, Nigeria

E-mail: jnnanna@devbankng.com 
Research Department

\title{
Governance and the Capital Flight Trap in Africa
}

\section{Simplice A. Asongu \& Joseph Nnanna}

January 2020

\begin{abstract}
The study examines the use of governance tools to fight capital flight by reducing the capital flight trap. Two overarching policy syndromes are addressed in the study. It first assesses whether governance is an effective deterrent to the capital flight trap in Africa, before examining what thresholds of government quality are required to fight the capital flight trap in the continent. The following findings are established. Evidence of a capital flight trap is apparent because past values of capital flight have a positive effect on future values of capital flight. The net effects from interactions of the capital flight trap with political stability, regulation quality, economic governance and corruption-control on capital flight are positive. The critical masses at which "voice \& accountability" and regulation quality can complement the capital flight trap to reduce capital flight are respectively, 0.120 and 0.680 , which correspond to the best performing countries. Policy implications are discussed.
\end{abstract}

JEL: C50; E62; F34; O55; P37

Keywords: governance; capital flight; capital flight trap; Africa 


\section{Introduction}

Two main questions are addressed by this study. On the one hand, it assesses whether governance is an effective deterrent to the capital flight trap in Africa ${ }^{2}$. On the other hand, it examines what critical masses of government quality are required to fight the persistence of capital flight in the continent. In order to tackle the overarching issues, the study is simultaneously concerned with avoiding the capital flight trap and capital flight. To avail room for more policy implications, we bundle and unbundle governance, notably: (i) political governance from "voice and accountability" and political stability; (ii) economic governance from regulation quality and government effectiveness and (iii) institutional governance from the rule of law and corruption-control.

The policy relevance of addressing the underlying questions builds on the negative development consequences of capital flight. Capital flight is the effect of an offshore financial economy that is substantially traceable to the absence of good governance (Gankou et al., 2016; Christensen, 2011; Ndikumana, 2016; Asongu, 2017a; Asongu \& Nwachukwu, 2017). There is a paradox between the increasing capital flight from Africa and the substantially documented need of finance for the continent's growing ambitions. On the one hand, the continent is a net creditor to the rest of the world because her capital outflows substantially surpass corresponding capital inflows (Boyce \& Ndikumana, 2012a; Asongu et al., 2019). For instance, according to the narrative, thirty-three countries in sub-Saharan Africa (SSA) lost approximately 814 billion US Dollars (in constant of 2010 terms) between 1970 and 2010, to capital flight. The lost amount is higher than either official development assistance or foreign direct investment received during the same period which stood respectively at 659 and 306 billion US Dollars.

On the other hand, the lack of financing is fundamental to Africa's poverty and underdevelopment (Darley, 2012; Boyce \& Ndikumana, 2012a; Tuomi, 2011; Bartels et al., 2009; Asongu \& Odhiambo, 2019a; Onifade et al., 2020a, 2020b). Accordingly, such lack of finance has limited socio-economic investment that is essential for the alleviation of poverty.

\footnotetext{
2 The capital flight trap can be defined as persistence in capital flight whereby past capital flight positively affects future capital flight. The conception and definition of the capital flight trap is consistent with contemporary literature on persistence in macroeconomic phenomena in which hysteresis in macroeconomic phenomena is apparent when past values of macroeconomic phenomena have a positive incidence on future values of the corresponding macroeconomic phenomena, notably: persistence in terrorism (Asongu, 2019) and inequality (Tchamyou, 2020a). In the attendant persistence literature, one lag is enough to capture past information. The one lag rule of thumb is consistent with the data of capital flight in this study because, the correlation between level and first lag series' of capital fight is high (i.e. exceeds the rule of thumb threshold of 0.800) while the correlation between the level and second lag series' is not high.
} 
This narrative culminates with a recent World Bank report on achievement of the Millennium Development Goals (MDGs) which has revealed that extreme poverty has been decreasing in all regions of the world with the exception of Africa where about $45 \%$ of countries in SSA were substantially off-track from achieving the MDGs extreme poverty target (World Bank, 2015; Tchamyou, 2019).

Accordingly, in spite of the growing bulk of capital flight (Ndiaye \& Siri, 2016; Mpenya et al., 2016) and governance (Kangoye, 2013; Musila \& Sigué, 2010) literature, not very much is known about the connections between capital flight, the capital flight trap and governance. Against this backdrop, this study has a threefold contribution to existing literature, notably, by: (i) advancing knowledge in evolving paradigms in the conception and definition of governance; (ii) addressing gaps in the literature and (iii) introducing the modelling of the capital flight trap. The third contribution is the most important.

First, the study complements a stream of literature on evolving paradigms in the definition; conception and measurement of governance (Asongu, 2016). To put this point into perspective, an inference is falsifiable if the term "political governance" is employed without the term being derived from a composite indicator that consists of both "political stability" and "voice \& accountability". In the same vein, it is inappropriate to use "economic governance" unless it is an embodiment of government effectiveness and regulation quality. Recent empirical examples of the employment of governance without a comprehensive appreciation include Kangoye (2013) who has used corruption-control and governance interchangeably. Accordingly, in the study under criticism, governance appears in the title whereas corruption-control is the main indicator. In essence, corruption-control is only an aspect of institutional governance. The study addresses the underlying issue by clearly articulating distinctions between various concepts of governance.

Second, whereas there is a growing body of literature on capital flight in Africa, the relationship between governance, the capital flight trap and capital flight has not received the scholarly attention it deserves. Contemporary literature for the most part, has focused on causes and consequences of capital flight, notably, on: the nexus between fiscal policy and capital flight (Muchai \& Muchai, 2016); determinants of capital flight in Ethiopia (Geda \& Yimer, 2016) and Madagascar (Ramiandrisoa \& Rakotomanana, 2016); capital flight and trade misinvoicing in Zimbabwe (Kwaramba et al., 2016); the relationship between natural resources and capital flight in Cameroon (Mpenya et al., 2016); the nexus between tax 
income and capital flight in Burkina Faso (Ndiaye \& Siri, 2016) and the connection between capital flight and public social expenditure in Congo-Brazzaville (Moulemvo, 2016).

Third, instead of focusing on the nexus between capital flight and governance, this study addresses the relationship between governance, the capital flight trap and capital flight, in order to assess how governance can be used as a policy tool to mitigate the role of the capital flight trap on capital flight. It is relevant to distinguish the capital flight trap from capital flight because both are policy syndromes that deserve policy and scholarly attention (Ndikumana \& Boyce, 2011a, 2011b; Boyce \& Ndikumana, 2001, 2011). Moreover, to the best of our knowledge, this is the first study in the capital flight literature to model how policy variables can be employed to fight a capital flight trap. Moreover, in the post-2015 development agenda, addressing how the sustainability of capital flight can be tackled should be more relevant to policy.

It is important to briefly discuss the theoretical connections between capital flight and governance, in the chronology of: political governance, economic governance and institutional governance. First, investors are very likely to respond to political instability and violence by disinvesting and transferring their capital to environments that are associated with lower risks in investment. Therefore, direct effects can be expected from political governance characteristics such as political instability, democracy and accountability. Moreover, government executives that stifle voice and accountability are likely to be rewarded with less capital inflows or more capital outflows. A political environment is an important determinant of capital flight because it is related to damages/losses of assets and/or changes in investmentrelated insurance premiums (Collier et al., 2004; Davies, 2008; Ndikumana et al., 2015). In addition, if portfolio investors lack confidence in domestic political institutions (e.g. competitive elections and executive accountability), it is very likely that they withdraw and/or divert their investments to countries that have more credible and stable political institutions. In summary, political environmental features influence security claims linked to foreign ownership as well as the performance of foreign markets (Lensink et al., 2000; Le \& Zak, 2006). Government officials are also more likely to siphon government funds and deposit in tax havens in the absence of political stability and "voice and accountability".

Second, investors can be discouraged from investing in an economy owing to an uncertain economic outlook, which is often the product of poor economic governance. In other words, investors have been documented to prefer less ambiguous investment climates (Kelsey \& le Roux, 2017, 2018). Poor governance can lead to substantial damages in the 
economy and such economic setbacks influence investors' perceptions about asset valuation. Hence, in the face of bleak macroeconomic prospects and a poor economic outlook, assets and money can easily be diverted from one country to another. From the perspective of government officials, in an atmosphere of poor economic governance, the formulation and implementation of policies that deliver public commodities could be designed to divert government funds to tax havens.

Third, on the connection between capital flight and institutional governance, we argue that both the rule of law and corruption-control affect the confidence that investors bestow on an economy and the capacity of public officials to siphon and divert funds to tax havens abroad. In essence, investors are less likely to put their money in an economic environment where disrespect of the rule of law is systemic. Such investors are also not very likely to engage in investing if they are reasonably convinced that economic governance can be weakened through predation by the State. Accordingly, respect of the rule of law guarantees: more property rights protection and investors that they would not be expropriated of their investments. Such expropriation discourages foreign investments and affects capital flight. In addition, countries that have corrupt executives often lack the commitment to respect the rights to private ownership and/or property rights. The narrative in this paragraph on the relationship between institutional governance and capital flight is consistent with recent literature on the nexus between institutional governance and industrialisation (Asongu \& Odhiambo, 2019b), notably, that investors prefer macroeconomic environments that are characterised by better information accounting standards (La Porta et al., 1998), efficient courts (Djankov et al., 2003) and enhanced institutions with less corrupt governments (La Porta et al., 1999). These tendencies have been confirmed in African-focused institutional studies (Asongu, 2012; Fowowe, 2014; Muazu \& Alagidede, 2017).

In the light of the above, the following testable hypotheses are examined in the empirical section of this study, namely: (i) Hypothesis 1 (Political governance decreases the positive incidence of the capital flight trap on capital flight); (ii) Hypothesis 2 (Economic governance reduces the positive influence of the capital flight trap on capital flight) and (iii) Hypothesis 3 (Institutional governance decreases the positive effect of the capital flight trap on capital flight). The two research questions disclosed in the first paragraph of this section are assessed by each of the three testable hypotheses. The rest of the study is structured as follows. Section 2 discusses research methods, while Section 3 presents the empirical results. Section 4 concludes with implications and future research directions. 


\section{Research methods}

\subsection{Data, measurements and control variables}

The study examines a panel of thirty-seven African countries using data for period 1996-2010 from three main sources, notably: (i) capital flight from Boyce and Ndikumana (2012a); (ii) governance variables from the World Bank Governance Indicators and (iii) macroeconomic economic control variables from the African Development Indicators of the World Bank. The periodicity of 1996-2010 is due to constraints in data availability at the time of the study. Whereas 2010 is the latest year for the capital flight data, good governance indicators are only available from 1996.

The dependent variable which is capital flight shows unrecorded capital flows between one country and the rest of the world. The measurement of these flows starts with inflows in foreign exchange that are considered in a country's balance of payments, such that, missing money (the difference between recorded inflows and corresponding outflows) is presented in terms of "net errors and omissions". The capital flight measurement is consistent with recent literature (Weeks, 2015; Efobi \& Asongu, 2016).

The main concern with the applicability of the capital flight indicator is the fact that it cannot be directly compared with other variables because it is disclosed in constant 2010 US Dollar terms. Borrowing from Asongu (2014a), the concern is addressed by: (i) transforming current GDP into constant 2010 terms; (ii) dividing the corresponding value by 1000000 to obtain a GDP constant of 2010 USD (in millions) and (iii) finally dividing the capital flight data by the GDP constant of 2010 USD (in millions). Ultimately, an indicator of capital flight is obtained that is comparable with other variables in terms of means and standard deviations (see Appendix 2).

The governance indicators from Kaufmann et al. (2010) are bundled in Section 2.1 by means of principal component analysis (PCA). Though unbundled, the six governance indicators have been used in recent governance literature (Oluwatobi et al., 2015; Andrés et al., 2015; Yerrabit \& Hawkes, 2015; Gani, 2011; Ajide \& Raheem, 2016a, 2016b).

In addition to the governance indicators, another independent variable of interest is the lagged value of capital flight that is used to assess the capital flight trap. This lagged value of capital flight is interacted with governance indicators in order to examine: (i) the net effect of governance and the capital flight trap on capital flight and (ii) thresholds of governance at which governance interacts with the capital flight trap to have a negative effect on capital flight. 
The study controls for the following variables in order to limit omission variable bias: public investment, foreign direct investment (FDI), inflation, GDP growth and trade openness. These control variables have been documented in a bulk of capital flight literature (Boyce \& Ndikumana, 1998, 2001, 2003, 2008, 2011, 2012a, 2012b; Weeks, 2012; Asongu, 2013, 2015). First, the expected signs from trade and FDI on capital flight cannot be easily established because they are contingent on whether FDI is limited to a few economic sectors or broad-based. Notwithstanding, it is very likely that trade and financial globalisation are associated with capital flight because of among others: more avenues for accounting malpractices like transfer mispricing (Ndikumana \& Sarr, 2016; Asongu \& AmankwahAmoah, 2018). Second, very high inflation, for the most part, positively influences capital flight because it is associated with a negative economic/investment outlook as well as uncertainty in investment return. This intuition is consistent with documented evidence that investors prefer investment strategies that are less ambiguous (Kelsey \& le Roux, 2017, 2018).

Third, the incidence of economic prosperity within the perspective of economic growth can either be positive or negative on capital flight contingent on whether the underlying economic growth is limited to specific sectors of the economy (e.g. heavy resource industries) or broadbased. On the one hand, broad-based economic growth can negatively influence capital flight because the investment outlook is more stable. On the other hand, economic growth that is skewed to select extractive industries is more likely to be positively linked to capital flight, in the light of the discourse on FDI and trade above. Fourth, the effect of public investment is contingent on its association with corruption-related activities. Accordingly, from an indirect angle, broad-based growth required to reduce capital flight may be less apparent when public investment is associated with corruption. From a direct perspective, funds that are siphoned by government officials in "public investment"-related contracts are more likely to be concealed in tax heavens abroad. This narrative on linkages between public investment, corruption and conditions for economic prosperity is consistent with Baliamoune-Lutz and Ndikumana (2008). The definition of variables and corresponding sources are provided in Appendix 1, the summary statistics in disclosed in Appendix 2 while the correlation matrix is presented in Appendix 3. 


\subsection{Data analysis techniques}

\subsubsection{Principal Component Analysis (PCA)}

Principal component analysis (PCA) is employed to bundle six governance indicators into three composite measurements, namely: economic, institutional and political governances. The PCA technique to bundling governance has recently been employed by Asongu and Nwachukwu (2016a) in the governance literature. Moreover, it is important to note that the PCA technique is appropriate for the sampled African countries because such a technique has been used in contemporary literature focusing on African samples (Tchamyou, 2017, 2020b). The technique consists of reducing the dimensions of a set of highly correlated variables into an uncorrelated smaller set of such variables known as principal components (PCs). The associated PCs reflect considerable information or variation from the main dataset. In the light of the PCA framework, the underlying six governance indicators from Kaufmann et al. (2010) are reduced to: (i) political governance (which consists of "voice \& accountability" and political stability); (ii) economic governance (entailing regulation quality and government effectiveness) and (iii) institutional governance (a composition of the rule of law and corruption-control). The derived PC-related indicators now have distinct definitions: (i) political governance is the election and replacement of political leaders; (ii) economic governance is the formulation and implementation of policies that deliver public commodities while (iii) institutional governance is the respect of the State and citizens of institutions that govern interactions between them.

The criterion used to select the PCs is from Kaiser (1974) and Jolliffe (2002). They have recommended that common factors to be retained should have eigenvalues of above one. As shown in Table 1 below: (i) political governance (Polgov) which summarises about $83.50 \%$ of information from political stability and 'voice \& accountability' has an eigenvalue of 1.671; (ii) economic governance (Ecogov) that represents approximately $93.90 \%$ of information from regulation quality and government effectiveness has an eigenvalue of 1.878 while (iii) institutional governance (Instgov) that denotes about $93.00 \%$ of information from the rule of law and corruption-control has an eigenvalue of 1.861 . 
Table 1: Principal Component Analysis (PCA) for Composite Governance

\begin{tabular}{|c|c|c|c|c|c|c|c|c|c|}
\hline \multirow{2}{*}{$\begin{array}{c}\text { Principal } \\
\text { Components }\end{array}$} & \multicolumn{6}{|c|}{ Component Matrix(Loadings) } & \multirow[t]{2}{*}{ Proportion } & $\begin{array}{l}\text { Cumulative } \\
\text { Proportion } \\
\end{array}$ & $\begin{array}{l}\text { Eigen } \\
\text { Value } \\
\end{array}$ \\
\hline & VA & PS & $\mathbf{R Q}$ & GE & $\mathbf{R L}$ & $\mathrm{CC}$ & & & \\
\hline First PC (Polgov) & 0.707 & 0.707 & --- & --- & --- & --- & 0.835 & 0.835 & 1.671 \\
\hline Second PC & -0.707 & 0.707 & --- & --- & --- & --- & 0.164 & 1.000 & 0.328 \\
\hline First PC (Ecogov) & -- & --- & 0.707 & 0.707 & --- & --- & 0.939 & 0.939 & 1.878 \\
\hline Second PC & --- & --- & -0.707 & 0.707 & -- & --- & 0.060 & 1.000 & 0.121 \\
\hline First PC (Instgov) & -- & -- & --- & --- & 0.70 & 0.707 & 0.930 & 0.930 & 1.861 \\
\hline Second PC & --- & --- & --- & --- & -0.707 & 0.707 & 0.069 & 1.000 & 0.138 \\
\hline
\end{tabular}

P.C: Principal Component. VA: Voice \& Accountability. RL: Rule of Law. R.Q: Regulation Quality. GE: Government Effectiveness. PS: Political Stability. CC: Control of Corruption. G.Gov (General Governance): First PC of VA, PS, RQ, GE, RL \& CC. Polgov (Political Governance): First PC of VA \& PS. Ecogov (Economic Governance): First PC of RQ \& GE. Instgov (Institutional Governance): First PC of RL \& CC.

We now devote space to engaging some important concerns that could arise from the use of regressors that are obtained from baseline regressions. Such issues are related to the efficiency, consistency and inferential validity of estimated coefficients (Asongu \& Nwachukwu, 2016a). Consistent with Pagan (1984, p.242), while estimates from two-step processes are efficient and consistent, corresponding inferences may not be valid. This caution on inferential validity is broadly in line with the bulk of empirical literature on the subject, notably: Oxley and McAleer (1993); McKenzie and McAleer (1997); Ba and Ng (2006) and Westerlund and Urbain (2013a).

Concerns surrounding the inferential quality of PCA-augmented variables have been documented by Westerlund and Urbain (2012, 2013b). The authors have built on a strand of literature on such concerns (Pesaran, 2006; Stock \& Watson, 2002; Bai, 2003; Bai, 2009; Greenaway-McGrevy et al., 2012) to establish that normal inferences can be made with PCaugmented regressors, so long as the corresponding estimated parameters converge to their real values at the rate of $\sqrt{N T}$, (with $\mathrm{T}$ being the number of time series and $\mathrm{N}$ denoting crosssection observations). The authors have further articulated that for the underlying convergence to occur, $\mathrm{T}$ and $\mathrm{N}$ have to be sufficiently large. Unfortunately, the authors do not emphasis "how large should be large" for such convergence to take place. Concerning the specific context of this inquiry, two major concerns are worth articulating. On the one hand, it is difficult to stretch $\mathrm{T}$ because capital flight data is up to the year 2010 while the governance indicators start from the year 1996. On the other hand, it is also unfeasible to stretch $\mathrm{N}$ because we have already engaged the 37 African countries in the capital flight database. In a nutshell, we argue that valid inferences are feasible because recent literature on PCaugmented regressors has used substantially lower values of $\mathrm{T}$ and $\mathrm{N}$ to established valid governance-related inferences (Asongu \& Nwachukwu, 2016a). 


\subsubsection{Estimation technique}

The selection of the estimation technique builds on contemporary literature on the importance of adopting an estimation technique that is consistent with the behavior of data $(\mathrm{Li}$ et al., 2014, 2016; Kou et al., 2012, 2014, 2016, 2019a, 2019b; Asongu, 2017b; Asongu \& Biekpe, 2017; Zhang et al., 2019). Hence, the choice of the estimation technique builds on five principal factors: while the first-two are basic requirements, the last-three are associated advantages (Tchamyou \& Asongu, 2017; Tchamyou et al., 2018). First, the technique enables the approach to control for a capital flight trap since the criterion for persistence in capital flight is met. Accordingly, the correlation between capital flight and the corresponding first lag is 0.867 which is higher than the 0.800 threshold needed to ascertain persistence in a dependent variable (Tchamyou, 2019, 2020b). Second, the $\mathrm{N}>\mathrm{T}$ (or 37>5) criterion that is required for the GMM strategy is fulfilled because the number of cross sections is higher than the number of time series in each cross section. Third, the estimation strategy accounts for potential endogeneity in all regressors by controlling for time invariant omitted variables on the one hand and simultaneity with instrumented regressors on the other hand. Fourth, crosscountry differences are considered in the regressions. Fifth, biases that are associated with the difference GMM strategy are tackled with the system GMM strategy.

In this study, the Roodman (2009a, 2009b) GMM approach is used. It is an extension of Arellano and Bover (1995) and employs forward orthogonal deviations as opposed to first differences. This extension has been documented to limit over-identification and restrict instrument proliferation (Love \& Zicchino, 2006; Baltagi, 2008; Tchamyou et al., 2019a). In the specification, a two-step procedure is adopted in place of a one-step process because it accounts for heteroscedasticity. The following equations in levels (1) and first difference (2) summarize the standard system GMM estimation procedure, where the independent variables of interest are specified to be one lag less contemporary.

$$
\operatorname{Cap}_{i, t}=\sigma_{0}+\sigma_{1} \operatorname{Cap}_{i, t-\tau}+\sigma_{2} \operatorname{Gov}_{i, t-1}+\sigma_{3} \operatorname{CapGov}_{i, t-1}+\sum_{h=1}^{5} \delta_{h} W_{h, i, t-\tau}+\eta_{i}+\xi_{t}+\varepsilon_{i, t}
$$

$$
\begin{aligned}
\operatorname{Cap}_{i, t}-\operatorname{Cap}_{i, t-\tau}= & \sigma_{1}\left(\operatorname{Cap}_{i, t-\tau}-\operatorname{Cap}_{i, t-2 \tau}\right)+\sigma_{2}\left(\operatorname{Gov}_{i, t-\tau}-\operatorname{Gov}_{i, t-2 \tau}\right)+\sigma_{3}\left(\operatorname{CapGov}_{i, t-\tau}-\operatorname{CapGov}_{i, t-2 \tau}\right) \\
& +\sum_{h=1}^{5} \delta_{h}\left(W_{h, i, t-\tau}-W_{h, i, t-2 \tau}\right)+\left(\xi_{t}-\xi_{t-\tau}\right)+\left(\varepsilon_{i, t}-\varepsilon_{i, t-\tau}\right)
\end{aligned}
$$

where, $\mathrm{Cap}_{i, t}$ is capital flight of country $i$ in period $t ; \mathrm{Cap}_{i, t-1}$ is capital flight of country $i$ in period $t-1$; Gov $v_{i, t-1}$ is governance (political, economic or institutional) of country $i$ in 
period $t-1 ; \sigma_{0}$ is a constant; $\tau$ represents the coefficient of auto-regression which is one because a lag of one year is enough to capture past information; $W$ is the vector of control variables (Trade, Growth, Inflation, FDI and Public Investment), $\eta_{i}$ is the country-specific effect, $\xi_{t}$ is the time-specific constant and $\varepsilon_{i, t}$ the error term.

\subsubsection{Identification, simultaneity and exclusion restrictions}

Discussing concerns surrounding identification, simultaneity and exclusion restrictions is paramount in the specification of GMM. As documented in recent literature (Dewan \& Ramaprasad, 2014; Asongu \& Nwachukwu, 2016b; Tchamyou et al., 2019b), all independent indicators are considered as predetermined or suspected endogenous while time-invariant omitted variables are considered as strictly exogenous. In essence, it is unfeasible for timeinvariant omitted indicators to become endogenous in first-difference (see Roodman, 2009b). Therefore, the approach for treating ivstyle (time invariant omitted variables) is 'iv(years, eq(diff))' whereas the gmmstyle is used for suspected endogenous variables.

The issue of simultaneity is tackled with lagged regressors used as instruments for forward differenced indicators. Accordingly, Helmert transformations are used to eliminate fixed effects that are likely to be correlated with the error terms and bias estimated linkages (Arellano \& Bover, 1995; Love \& Zicchino, 2006). These transformations consist of using forward mean-variations of variables which is contrary to the procedure of deducting previous observations from present ones (Roodman, 2009b, p.104). In essence, the mean of future observations is subtracted from the previous indicators. This transformation provides parallel or orthogonal conditions between the forward-differenced variables and lagged values. Regardless of the number of lags, the loss of data is avoided by computing the suggested transformations for all observations with the exception of each cross section's last observation: "And because lagged observations do not enter the formula, they are valid as instruments" (Roodman (2009b, p. 104).

In the light of the above, capital flight is affected by the time invariant omitted variables exclusively through predetermined or suspected endogenous variables. In addition, the statistical solidity of the exclusion restriction is examined with the Difference in Hansen Test (DHT) for the validity of instruments. Accordingly, in order for time invariant indicators to elucidate capital flight exclusively via the endogenous explaining variables, the alternative hypothesis of the test should be rejected. It is interesting to note that whereas with an instrumental variable (IV) estimation technique, failing to accept the alternative hypothesis of 
the Sargan Overidentifying Restrictions (OIR) test is an indication that the instruments elicit the outcome variable exclusively via the suspected endogenous variables (Beck et al., 2003; Asongu \& Nwachukwu, 2016c), with the current GMM technique, the information criterion used to investigate if time invariant omitted variables are strictly exogenous is the DHT. Hence, based on these clarifications, the hypothesis of exclusive restriction is confirmed if the null hypothesis of the DHT linked with IV(year, eq(diff)) is not rejected.

\section{Empirical results}

Table 2 (examining Hypothesis 1), Table 3 (assessing Hypothesis 2) and Table 4 (investigating Hypothesis 3) respectively present findings related to political governance, economic governance and institutional governance. Four principal information criteria are employed to examine the validity of the GMM model with forward orthogonal deviations ${ }^{3}$. Consistent with the two main questions motivating the study, we compute: (i) the net effect of governance and the capital flight trap on capital flight and (ii) thresholds of governance at which governance interacts with the capital flight trap to have a negative effect on capital flight. For instance in the last column of Table 3, the unconditional and conditional effects of capital flight trap are respectively: 0.483 and -0.120 . The corresponding economic governance threshold at which the unconditional positive effect of the capital flight trap on capital flight is reduced by economic governance is $4.025(0.483 / 0.120)$ whereas the net effect is 0.462 $(0.483+[-0.120 \times 0.172])^{4}$. Unfortunately, the threshold or critical mass of 4.025 does not make economic sense because it is not within the range (-3.284 to 3.276) provided by the summary statistics.

The following findings can be established from Table 2. Evidence of a capital flight trap is apparent because past values of capital flight have a positive effect on future values of capital flight. The net effect from the role of political stability in the capital flight trap is positive. The threshold at which "voice \& accountability" can complement the capital flight trap to reduce capital flight is 0.120 . This threshold has economic significance because it is

\footnotetext{
3 "First, the null hypothesis of the second-order Arellano and Bond autocorrelation test (AR(2)) in difference for the absence of autocorrelation in the residuals should not be rejected. Second the Sargan and Hansen overidentification restrictions (OIR) tests should not be significant because their null hypotheses are the positions that instruments are valid or not correlated with the error terms. In essence, while the Sargan OIR test is not robust but not weakened by instruments, the Hansen OIR is robust but weakened by instruments. In order to restrict identification or limit the proliferation of instruments, we have ensured that instruments are lower than the number of cross-sections in most specifications. Third, the Difference in Hansen Test (DHT) for exogeneity of instruments is also employed to assess the validity of results from the Hansen OIR test. Fourth, a Fisher test for the joint validity of estimated coefficients is also provided" (Asongu \& De Moor, 2017, p.200).

${ }^{4} 0.172$ is the mean value of Economic Governance.
} 
within the "voice \& accountability" range (-1.885 to 0.932$)$ disclosed in the summary statistics. Most of the significant control variables have expected signs.

The following findings can be established from Table 3 on the linkages between capital flight, the capital flight trap and economic governance. There is evidence of a capital flight trap because past values of capital flight have a positive effect on future values of capital flight. The net effects from the roles of regulation quality and economic governance are positive. The threshold at which regulation quality can complement the capital flight trap to reduce capital flight is 0.680 , just close of the maximum disclosed by the range $(-2.412$ to 0.791) of the summary statistics. The thresholds at which economic governance can complement the capital flight trap to reduce capital flight do not make economic sense because they are not within the ranges provided by the summary statistics. Most of the significant control variables have expected signs.

The following findings can be established from Table 4 on the linkages between capital flight, the capital flight trap and institutional governance. There is evidence of a capital flight trap because past values of capital flight have a positive effect on future values of capital flight. The net effect from the role of corruption-control is positive. Most of the significant control variables have expected signs. 
Table 2: Capital flight trap and political governance (Hypothesis 1)

\begin{tabular}{|c|c|c|c|c|c|c|}
\hline \multirow[b]{3}{*}{ Constant } & \multicolumn{6}{|c|}{ Dependent variable: Capital Flight } \\
\hline & \multicolumn{2}{|c|}{ Political Stability } & \multicolumn{2}{|c|}{ Voice and Accountability } & \multicolumn{2}{|c|}{ Political Governance } \\
\hline & $\begin{array}{l}5.866 * * * \\
(0.000)\end{array}$ & $\begin{array}{l}8.136 * * * \\
(0.000)\end{array}$ & $\begin{array}{l}9.783 * * * \\
(0.000)\end{array}$ & $\begin{array}{l}8.908 * * * \\
(0.000)\end{array}$ & $\begin{array}{l}8.492 * * * * \\
(0.000)\end{array}$ & $\begin{array}{l}6.590 * * * \\
(0.000)\end{array}$ \\
\hline Capital Flight(CF) (-1) & $\begin{array}{l}0.390 * * * \\
(0.002)\end{array}$ & $\begin{array}{l}0.213 \\
(0.234)\end{array}$ & $\begin{array}{l}0.018 \\
(0.861)\end{array}$ & $\begin{array}{l}0.106 \\
(0.566)\end{array}$ & $\begin{array}{l}0.162 * * * \\
(0.003)\end{array}$ & $\begin{array}{l}0.386 * * * \\
(0.006)\end{array}$ \\
\hline Political Stability(-1) & $\begin{array}{l}-1.174 * \\
(0.071)\end{array}$ & $\begin{array}{l}0.631 \\
(0.523)\end{array}$ & --- & --- & --- & --- \\
\hline Voice \& Accountability(-1) & --- & --- & $\begin{array}{l}1.359 * * \\
(0.047)\end{array}$ & $\begin{array}{l}1.332 \\
(0.166)\end{array}$ & --- & --- \\
\hline Political Governance(-1) & --- & --- & --- & --- & $\begin{array}{l}0.436 \\
(0.202)\end{array}$ & $\begin{array}{l}0.487 \\
(0.370)\end{array}$ \\
\hline Political Stability $(-1) \times \mathrm{CF}(-1)$ & $\begin{array}{l}0.113 * \\
(0.090)\end{array}$ & $\begin{array}{l}-0.075 \\
(0.461)\end{array}$ & --- & --- & --- & --- \\
\hline Voice \& Accountability $(-1) \times \mathrm{CF}(-1)$ & --- & --- & $\begin{array}{l}-0.150 * * \\
(0.034)\end{array}$ & $\begin{array}{l}-0.126 \\
(0.214)\end{array}$ & --- & --- \\
\hline Political Governance $(-1) \times \mathrm{CF}(-1)$ & --- & --- & --- & --- & $\begin{array}{l}-0.044 \\
(0.229)\end{array}$ & $\begin{array}{l}-0.047 \\
(0.414)\end{array}$ \\
\hline Trade Openness & $\begin{array}{l}0.001 * * \\
(0.044)\end{array}$ & $\begin{array}{l}0.0008 \\
(0.648)\end{array}$ & $\begin{array}{l}0.002 * * * \\
(0.001)\end{array}$ & $\begin{array}{l}0.001 \\
(0.242)\end{array}$ & $\begin{array}{l}0.002 * * * \\
(0.003)\end{array}$ & $\begin{array}{l}0.002 \\
(0.130)\end{array}$ \\
\hline GDP growth & $\begin{array}{l}-0.005 * * \\
(0.047)\end{array}$ & $\begin{array}{l}-0.006 \\
(0.267)\end{array}$ & $\begin{array}{l}-0.004 * \\
(0.058)\end{array}$ & $\begin{array}{l}-0.003 \\
(0.595)\end{array}$ & $\begin{array}{l}-0.004 * \\
(0.063)\end{array}$ & $\begin{array}{l}-0.007 \\
(0.234)\end{array}$ \\
\hline Inflation & $\begin{array}{l}0.004 * * * \\
(0.000)\end{array}$ & $\begin{array}{l}0.002 * * * * \\
(0.003)\end{array}$ & $\begin{array}{l}0.003 * * * \\
(0.000)\end{array}$ & $\begin{array}{l}0.004 * * * \\
(0.000)\end{array}$ & $\begin{array}{l}0.003 * * * \\
(0.000)\end{array}$ & $\begin{array}{l}0.002 * * * * \\
(0.001)\end{array}$ \\
\hline Foreign Direct Investment & --- & $\begin{array}{l}-0.007 \\
(0.190)\end{array}$ & --- & $\begin{array}{l}-0.013 * * * * \\
(0.001)\end{array}$ & --- & $\begin{array}{l}-0.012 * * \\
(0.017)\end{array}$ \\
\hline Public Investment & --- & $\begin{array}{l}-0.010 \\
(0.200)\end{array}$ & --- & $\begin{array}{l}-0.021 * * * * \\
(0.002)\end{array}$ & --- & $\begin{array}{l}-0.015 * \\
(0.064)\end{array}$ \\
\hline Net effects & 0.318 & n.a & n.a & n.a & n.a & n.a \\
\hline Thresholds & n.s.a & n.a & 0.120 & n.a & n.a & n.a \\
\hline $\mathrm{AR}(1)$ & $(0.000)$ & $(0.000)$ & $(0.000)$ & $(0.005)$ & $(0.000)$ & $(0.001)$ \\
\hline $\mathrm{AR}(2)$ & $(0.249)$ & $(0.284)$ & $(0.556)$ & $(0.390)$ & $(0.380)$ & $(0.091)$ \\
\hline Sargan OIR & $(0.000)$ & $(0.000)$ & $(0.000)$ & $(0.000)$ & $(0.000)$ & $(0.000)$ \\
\hline Hansen OIR & $(0.347)$ & $(0.998)$ & $(0.539)$ & $(0.992)$ & $(0.316)$ & $(0.999)$ \\
\hline $\begin{array}{l}\text { DHT for instruments } \\
\text { (a)Instruments in levels }\end{array}$ & & & & & & \\
\hline $\mathrm{H}$ excluding group & $(0.572)$ & $(0.781)$ & $(0.559)$ & $(0.598)$ & $(\mathbf{0 . 5 5 3})$ & $(0.769)$ \\
\hline $\begin{array}{l}\text { Dif(null, H=exogenous) } \\
\text { (b) IV (years, eq(diff)) }\end{array}$ & $(0.246)$ & (0.999) & $(0.454)$ & (0.998) & $(0.224)$ & $(0.999)$ \\
\hline $\mathrm{H}$ excluding group & $(0.154)$ & $(0.665)$ & $(\mathbf{0 . 3 5 3})$ & $(0.608)$ & $(0.211)$ & $(0.868)$ \\
\hline Dif(null, $\mathrm{H}=$ exogenous) & $(0.604)$ & (1.000) & $(0.615)$ & (1.000) & $(0.463)$ & (1.000) \\
\hline Fisher & $223.21 * * *$ & $1756.34 * * *$ & $8026.11 * * *$ & $1065.96 * * *$ & $2686.48 * * *$ & $865.04 * * *$ \\
\hline Countries & 33 & 32 & 33 & 32 & 33 & 32 \\
\hline Observations & 302 & 265 & 302 & 265 & 302 & 265 \\
\hline
\end{tabular}

$*, * * * * *$ : significance levels of 10\%, 5\% and 1\% respectively. DHT: Difference in Hansen Test for Exogeneity of Instruments' Subsets. Dif: Difference. OIR: Over-identifying Restrictions Test. The significance of bold values is twofold. 1) The significance of estimated coefficients and the Fisher statistics. 2) The failure to reject the null hypotheses of: a) no autocorrelation in the AR(1) and $\operatorname{AR}(2)$ tests and; b) the validity of the instruments in the Sargan and Hansen OIR test. na: not applicable due to the insignificance of conditional effects. 
Table 3: Capital flight trap and economic governance (Hypothesis 2)

\begin{tabular}{|c|c|c|c|c|c|c|}
\hline \multirow[b]{3}{*}{ Constant } & \multicolumn{6}{|c|}{ Dependent variable: Capital Flight } \\
\hline & \multicolumn{2}{|c|}{ Regulation Quality } & \multicolumn{2}{|c|}{ Government Effectiveness } & \multicolumn{2}{|c|}{ Economic Governance } \\
\hline & $\begin{array}{l}\mathbf{8 . 8 3 5}^{* * * *} \\
(\mathbf{0 . 0 0 0 )}\end{array}$ & $\begin{array}{l}7.213 * * * \\
(0.000)\end{array}$ & $\begin{array}{l}10.053 * * * \\
(0.000)\end{array}$ & $\begin{array}{l}6.768 * * * \\
(0.000)\end{array}$ & $\begin{array}{l}5.898 * * * \\
(0.000)\end{array}$ & $\begin{array}{l}5.368 * * * \\
(0.000)\end{array}$ \\
\hline Capital Flight(CF) (-1) & $\begin{array}{l}0.102 \\
(0.361)\end{array}$ & $\begin{array}{l}0.303 * * \\
(0.026)\end{array}$ & $\begin{array}{l}0.007 \\
(0.958)\end{array}$ & $\begin{array}{l}0.357 * * \\
(0.015)\end{array}$ & $\begin{array}{l}0.397 * * * \\
(0.000)\end{array}$ & $\begin{array}{l}\mathbf{0 . 4 8 3} * * * \\
(\mathbf{0 . 0 0 0 )})\end{array}$ \\
\hline Regulation Quality(-1) & $\begin{array}{l}1.609 * \\
(0.070)\end{array}$ & $\begin{array}{l}1.367 * \\
(0.096)\end{array}$ & --- & --- & --- & --- \\
\hline Government Effectiveness (-1) & --- & --- & $\begin{array}{l}2.418 * \\
(0.092)\end{array}$ & $\begin{array}{l}0.941 \\
(0.519)\end{array}$ & --- & --- \\
\hline Economic Governance (-1) & --- & --- & --- & --- & $\begin{array}{l}0.933 * \\
(0.045)\end{array}$ & $\begin{array}{l}1.297 * * \\
(0.023)\end{array}$ \\
\hline Regulation Quality × CF(-1) & $\begin{array}{l}-0.150 * \\
(0.097)\end{array}$ & $\begin{array}{l}-0.124 \\
(0.151)\end{array}$ & --- & --- & --- & --- \\
\hline Government Effectiveness $(-1) \times \mathrm{CF}(-1)$ & --- & --- & $\begin{array}{l}-0.234 \\
(0.114)\end{array}$ & $\begin{array}{l}-0.079 \\
(0.594)\end{array}$ & --- & --- \\
\hline Economic Governance $(-1) \times \mathrm{CF}(-1)$ & --- & --- & --- & --- & $\begin{array}{l}-0.083 * \\
(0.073)\end{array}$ & $\begin{array}{l}-0.120 * * \\
(0.041)\end{array}$ \\
\hline Trade Openness & $\begin{array}{l}0.0008 \\
(0.195)\end{array}$ & $\begin{array}{l}0.001 \\
(0.398)\end{array}$ & $\begin{array}{l}0.002 * * * \\
(0.002)\end{array}$ & $\begin{array}{l}0.001 \\
(0.123)\end{array}$ & $\begin{array}{l}-0.0002 \\
(0.739)\end{array}$ & $\begin{array}{l}0.00009 \\
(0.948)\end{array}$ \\
\hline GDP growth & $\begin{array}{l}0.004 * \\
(0.090)\end{array}$ & $\begin{array}{l}0.001 \\
(0.794)\end{array}$ & $\begin{array}{l}-0.0003 \\
(0.859)\end{array}$ & $\begin{array}{l}-0.003 \\
(0.575)\end{array}$ & $\begin{array}{l}0.0009 \\
(0.652)\end{array}$ & $\begin{array}{l}-0.006 \\
(0.327)\end{array}$ \\
\hline Inflation & $\begin{array}{l}0.004 * * * \\
(0.000)\end{array}$ & $\begin{array}{l}0.003 * * * \\
(0.000)\end{array}$ & $\begin{array}{l}0.003 * * * \\
(0.000)\end{array}$ & $\begin{array}{l}0.002 * * * \\
(0.000)\end{array}$ & $\begin{array}{l}0.003 * * * * * \\
(0.000)\end{array}$ & $\begin{array}{l}0.002 * * * \\
(0.000)\end{array}$ \\
\hline Foreign Direct Investment & --- & $\begin{array}{l}-0.004 \\
(0.338)\end{array}$ & --- & $\begin{array}{l}-0.006 \\
(0.183)\end{array}$ & --- & $\begin{array}{l}-0.003 \\
(0.479)\end{array}$ \\
\hline Public Investment & --- & $\begin{array}{l}-0.006 \\
(0.500)\end{array}$ & --- & $\begin{array}{l}-0.016 * * * \\
(0.015)\end{array}$ & --- & $\begin{array}{l}0.001 \\
(0.865)\end{array}$ \\
\hline Net effects & 0.196 & n.a & n.a & n.a & 0.382 & 0.462 \\
\hline Thresholds & 0.680 & n.a & n.a & n.a & 4.783 & 4.025 \\
\hline $\mathrm{AR}(1)$ & $(0.001)$ & $(0.001)$ & $(0.002)$ & $(0.000)$ & $(0.001)$ & $(0.000)$ \\
\hline $\mathrm{AR}(2)$ & $(0.300)$ & $(0.151)$ & $(0.396)$ & $(0.485)$ & $(0.156)$ & $(0.542)$ \\
\hline Sargan OIR & $(0.000)$ & $(0.000)$ & $(0.000)$ & $(0.000)$ & $(0.000)$ & $(0.000)$ \\
\hline Hansen OIR & $(0.422)$ & $(0.907)$ & $(0.473)$ & $(0.997)$ & $(0.428)$ & $(0.968)$ \\
\hline $\begin{array}{l}\text { DHT for instruments } \\
\text { (a)Instruments in levels }\end{array}$ & & & & & & \\
\hline H excluding group & $(0.635)$ & $(0.589)$ & $(0.438)$ & $(0.873)$ & $(0.716)$ & (0.739) \\
\hline $\begin{array}{l}\text { Dif(null, H=exogenous) } \\
\text { (b) IV (years, eq(diff)) }\end{array}$ & $(0.292)$ & $(0.913)$ & $(0.452)$ & (0.993) & $(0.264)$ & $(0.956)$ \\
\hline $\mathrm{H}$ excluding group & $(0.115)$ & $(0.153)$ & $(0.243)$ & (0.439) & $(0.398)$ & $(0.584)$ \\
\hline Dif(null, H=exogenous) & (0.798) & (1.000) & $(0.650)$ & (1.000) & (0.428) & (1.000) \\
\hline Fisher & $9607.90 * * *$ & $1822.99 * * *$ & $2917.87 * * *$ & $1109.39 * * *$ & $3304.13 * * *$ & $1650.51 * * *$ \\
\hline Countries & 33 & 32 & 33 & 32 & 33 & 32 \\
\hline Observations & 302 & 265 & 301 & 264 & 301 & 264 \\
\hline
\end{tabular}

***,***: significance levels of 10\%, 5\% and 1\% respectively. DHT: Difference in Hansen Test for Exogeneity of Instruments' Subsets. Dif: Difference. OIR: Over-identifying Restrictions Test. The significance of bold values is twofold. 1) The significance of estimated coefficients and the Fisher statistics. 2) The failure to reject the null hypotheses of: a) no autocorrelation in the AR(1) and $\operatorname{AR}(2)$ tests and; b) the validity of the instruments in the Sargan and Hansen OIR test. na: not applicable due to the insignificance of conditional effects. 
Table 4: Capital flight trap and institutional governance (Hypothesis 3)

\begin{tabular}{|c|c|c|c|c|c|c|}
\hline \multirow[b]{3}{*}{ Constant } & \multicolumn{6}{|c|}{ Dependent variable: Capital Flight } \\
\hline & \multicolumn{2}{|c|}{ Rule of Law } & \multicolumn{2}{|c|}{ Corruption Control } & \multicolumn{2}{|c|}{ Institutional Governance } \\
\hline & $\begin{array}{l}9.713 * * * \\
(0.000)\end{array}$ & $\begin{array}{l}8.167 * * * \\
(0.000)\end{array}$ & $\begin{array}{l}5.291 * * * \\
(0.003)\end{array}$ & $\begin{array}{l}4.897 * * * \\
(0.002)\end{array}$ & $\begin{array}{l}7.338 * * * \\
(0.000)\end{array}$ & $\begin{array}{l}5.618 * * * \\
(0.000)\end{array}$ \\
\hline Capital Flight(CF) (-1) & $\begin{array}{l}0.036 \\
(0.797)\end{array}$ & $\begin{array}{l}0.185 \\
(0.199)\end{array}$ & $\begin{array}{l}0.460 * * * \\
(0.008)\end{array}$ & $\begin{array}{l}0.529 * * * \\
(0.001)\end{array}$ & $\begin{array}{l}0.270 * * * \\
(0.000)\end{array}$ & $\begin{array}{l}\mathbf{0 . 4 5 3} * * * \\
(\mathbf{0 . 0 0 0 )}\end{array}$ \\
\hline Rule of Law(-1) & $\begin{array}{l}0.911 \\
(0.353)\end{array}$ & $\begin{array}{l}0.884 \\
(0.338)\end{array}$ & --- & --- & --- & --- \\
\hline Corruption Control(-1) & --- & --- & $\begin{array}{l}-2.602 * \\
(0.072)\end{array}$ & $\begin{array}{l}-0.424 \\
(0.762)\end{array}$ & --- & --- \\
\hline Institutional Governance (-1) & --- & --- & --- & --- & $\begin{array}{l}-0.007 \\
(0.979)\end{array}$ & $\begin{array}{l}0.416 \\
(0.457)\end{array}$ \\
\hline Rule of $\operatorname{Law}(-1) \times \operatorname{CF}(-1)$ & $\begin{array}{l}-0.095 \\
(0.46)\end{array}$ & $\begin{array}{l}-0.076 \\
(0.402)\end{array}$ & --- & --- & --- & --- \\
\hline Corruption Control(-1) $\times \mathrm{CF}(-1)$ & --- & --- & $\begin{array}{l}0.247 * \\
(0.087)\end{array}$ & $\begin{array}{l}0.040 \\
(0.766)\end{array}$ & --- & --- \\
\hline Institutional Governance $(-1) \times \mathrm{CF}(-1)$ & --- & --- & --- & --- & $\begin{array}{l}0.0003 \\
(0.991)\end{array}$ & $\begin{array}{l}-0.037 \\
(0.516)\end{array}$ \\
\hline Trade Openness & $\begin{array}{l}0.002 * * * \\
(0.001)\end{array}$ & $\begin{array}{l}0.002 * \\
(0.082)\end{array}$ & $\begin{array}{l}0.003 * * * \\
(0.002)\end{array}$ & $\begin{array}{l}0.001 \\
(0.495)\end{array}$ & $\begin{array}{l}0.003 * * * \\
(0.004)\end{array}$ & $\begin{array}{l}0.002 * * \\
(0.049)\end{array}$ \\
\hline GDP growth & $\begin{array}{l}-0.005 * \\
(0.059)\end{array}$ & $\begin{array}{l}-0.001 \\
(0.789)\end{array}$ & $\begin{array}{l}-0.004 \\
(0.167)\end{array}$ & $\begin{array}{l}0.0001 \\
(0.973)\end{array}$ & $\begin{array}{l}-0.007 * * \\
(0.029)\end{array}$ & $\begin{array}{l}-0.003 \\
(0.345)\end{array}$ \\
\hline Inflation & $\begin{array}{l}0.003 * * * \\
(0.000)\end{array}$ & $\begin{array}{l}0.004 * * * \\
(0.000)\end{array}$ & $\begin{array}{l}0.004 * * * \\
(0.000)\end{array}$ & $\begin{array}{l}\mathbf{0 . 0 0 2} * * * \\
(\mathbf{0 . 0 0 0 )}\end{array}$ & $\begin{array}{l}0.003 * * * \\
(0.000)\end{array}$ & $\begin{array}{l}0.002 * * * * \\
(0.000)\end{array}$ \\
\hline Foreign Direct Investment & --- & $\begin{array}{l}-0.013 * * * \\
(0.000)\end{array}$ & --- & $\begin{array}{l}-0.001 \\
(0.756)\end{array}$ & --- & $\begin{array}{l}-0.006 \\
(0.110)\end{array}$ \\
\hline Public Investment & --- & $\begin{array}{l}-0.019 * * * \\
(0.002)\end{array}$ & --- & $\begin{array}{l}-0.011 \\
(0.156)\end{array}$ & --- & $\begin{array}{l}-0.008 \\
(0.279)\end{array}$ \\
\hline Net effects & n.a & n.a & 0.288 & n.a & n.a & n.a \\
\hline Thresholds & n.a & n.a & n.a & n.a & n.a & n.a \\
\hline $\begin{array}{l}\operatorname{AR}(1) \\
\operatorname{AR}(2) \\
\text { Sargan OIR } \\
\text { Hansen OIR }\end{array}$ & $\begin{array}{l}(0.000) \\
(\mathbf{0 . 5 5 8}) \\
(0.000) \\
(\mathbf{0 . 9 3 4 )}\end{array}$ & $\begin{array}{l}(0.004) \\
(\mathbf{0 . 2 7 0}) \\
(0.000) \\
(\mathbf{0 . 9 9 6 )}\end{array}$ & $\begin{array}{l}(0.000) \\
(\mathbf{0 . 1 0 9}) \\
(0.000) \\
(\mathbf{0 . 4 9 1})\end{array}$ & $\begin{array}{l}(0.000) \\
(\mathbf{0 . 1 0 5}) \\
(0.000) \\
(\mathbf{0 . 9 6 2 )}\end{array}$ & $\begin{array}{l}(0.000) \\
(\mathbf{0 . 2 6 8}) \\
(0.000) \\
(\mathbf{0 . 6 2 4})\end{array}$ & $\begin{array}{l}(0.022) \\
(\mathbf{0 . 3 2 0}) \\
(0.000) \\
(\mathbf{0 . 9 4 4 )}\end{array}$ \\
\hline $\begin{array}{l}\text { DHT for instruments } \\
\text { (a)Instruments in levels }\end{array}$ & & & & & & \\
\hline $\mathrm{H}$ excluding group & $(0.690)$ & $(0.878)$ & $(0.516)$ & $(0.813)$ & $(0.523)$ & $(0.550)$ \\
\hline $\begin{array}{l}\text { Dif(null, H=exogenous) } \\
\text { (b) IV (years, eq(diff)) }\end{array}$ & $(0.910)$ & $(0.990)$ & $(0.425)$ & $(0.922)$ & $(0.578)$ & $(0.966)$ \\
\hline $\mathrm{H}$ excluding group & $(0.449)$ & $(0.525)$ & $(0.609)$ & $(0.344)$ & $(0.495)$ & $(0.688)$ \\
\hline Dif(null, $\mathrm{H}=$ exogenous) & $(0.988)$ & (1.000) & $(0.361)$ & (1.000) & $(0.602)$ & (0.970) \\
\hline Fisher & $3058.09 * * *$ & $1430.96 * * *$ & $4386.61 * * *$ & $527.25 * * *$ & $9194.55 * * *$ & $218.34 * * *$ \\
\hline Countries & 33 & 32 & 33 & 32 & 33 & 32 \\
\hline Observations & 302 & 265 & 301 & 264 & 301 & 264 \\
\hline
\end{tabular}

$*, * *, * * *$ : significance levels of $10 \%, 5 \%$ and $1 \%$ respectively. DHT: Difference in Hansen Test for Exogeneity of Instruments' Subsets. Dif: Difference. OIR: Over-identifying Restrictions Test. The significance of bold values is twofold. 1) The significance of estimated coefficients and the Fisher statistics. 2) The failure to reject the null hypotheses of: a) no autocorrelation in the AR(1) and AR(2) tests and; b) the validity of the instruments in the Sargan and Hansen OIR test. na: not applicable due to the insignificance of conditional effects. 
It is relevant to clarify that while net effects and corresponding thresholds could not be computed for most of the estimations in Tables 2-4 because at least one estimated coefficient essential for such computation is not significant; the study argues that both statistically significant and statistically insignificant estimates have economic meaning. In the light of the arguments from the literature used to substantiate the testable hypotheses in the introduction, it was expected that the governance dynamics would modulate the capital flight trap to induce net negative effects on capital flight. However, the findings are disclosed in order to avoid publication bias in social science scholarship where authors prefer to submit only strong, expected and significant findings for publication because of the peer review culture of rejecting manuscripts with weak, unexpected and insignificant results (Rosenberg, 2005; Franco et al., 2014; Boateng et al., 2018). It what follows, the economic significance of the unexpected findings is clarified in the light of the time and level assumptions underpinning the benefits of governance in development outcomes.

In the light of the above, governance standards should be increased in order for sampled countries to gain from the time and level assumptions for the rewards of governance in moderating the capital flight trap to induce negative net effects on capital flight. It is important to note that, the favourable impacts of governance in development outcomes have been tested independently to establish a non-linear relationship between democracy-driven governance standards and development outcomes in developing nations (Sung, 2004; Asongu, 2014b). First, on the premise of the level assumption, the attendant literature (Sung, 2004; Back \& Hadenius, 2008; Asongu \& Nwachukwu, 2016d) has established that countries with strong democracies enjoy the highest standards of governance; countries with partiallydemocratic standards are associated with the least standard of governance while authoritarian countries enjoy average governance levels. Second, with respect to the time of exposure assumption, authoritarian regimes are associated with better governance standards compared to young democracies while strong democracies enjoy the highest standards of governance (Keefer, 2007). It follows that because democracies in sampled countries are both weak (level assumption) and young (time of exposure assumption), the corresponding governance standards are not yet very strong. This explanation is consistent with the negative skewness that characterizes the governance dynamics disclosed in the summary statistics. Accordingly, the negative skeweness is assessed from the fact that: (i) mean values of the governance dynamics are negative and corresponding minimum values are greater in magnitude compared 
to the attendant maximum values. How governments in sampled countries can improve governance standards is discussed in the concluding section.

\section{Concluding implications and further research directions}

Two overarching policy syndromes have been addressed in this inquiry. It has first assessed whether governance is an effective deterrent to the capital flight trap in Africa, before examining what thresholds of government quality are required to fight the capital flight trap in the continent. For these purposes, using principal component analysis and interactive Generalised Method of Moments, we have bundled and unbundled nine governance indicators in 37 African countries for the period 1996-2010.

The bundled governance variables are: (i) political governance (encompassing political stability and "voice \& accountability"); (ii) economic governance (represented by government effectiveness and regulation quality) and (iii) institutional governance (entailing the rule of law and corruption-control). To provide responses to the two main questions, three hypotheses are tested, namely: (i) Hypothesis 1 (Political governance decreases the positive incidence of the capital flight trap on capital flight); (ii) Hypothesis 2 (Economic governance reduces the positive influence of the capital flight trap on capital flight) and (iii) Hypothesis 3 (Institutional governance decreases the positive effect of the capital flight trap on capital flight).

The following findings have been established on linkages between capital flight, capital flight trap and governance. Evidence of a capital flight trap is apparent because past values of capital flight have a positive effect on future values of capital flight. The net effects from interactions of the capital flight trap with political stability, regulation quality, economic governance and corruption-control on capital flight are positive. The critical masses at which "voice \& accountability" and regulation quality can complement the capital flight trap to reduce capital flight are respectively 0.120 and 0.680 , which correspond to best performing countries.

There are two direct implications from the study. On the one hand, the positive net effects imply that the current governance climate in Africa is not enough to fight the capital flight trap. Hence, improvements in political governance, economic governance and institutional governance are imperative to significantly reduce capital flight. On the other hand, the fact that thresholds or critical masses of regulation quality and "voce \& accountability" are close to the maximum range of the summary statistics imply that only a 
few best performing countries at the moment can successfully use governance tools to fight capital flight by reducing the capital flight trap. This point is consistent with the preceding inference that much needs to be done in terms of improving governance standards in view of mitigating capital flight.

Consistent with Asongu and Odhiambo (2020), the improvement of governance standards for favorable macroeconomic outcomes is largely traceable to the fact that the governance standards from World Development Indicators of the World Bank used in this study have both positive and negative values. Moreover, as we have established in the previous section, the governance dynamics used in this study are negatively skewed. In what follows, measures that can be implemented to improve political, economic and institutional dimensions of governance are discussed.

First, political governance can be improved by enhancing conditions for the election and replacement of political leaders. Measures to enhance political governance include, inter alia: (i) mitigation of incidences that can positively influence the ability of governments in the sampled nations to be overthrown via unconstitutional and violent channels which often involve political strife and terrorism. (ii) Improvement of the ability of citizens to be actively involved in the selection of government officials as well as the right of citizens to enjoy freedoms of expression, association and access to media.

Second, on the front of economic governance, substantial ameliorations are worthwhile in the formulation and implementation of measures that deliver public commodities especially in the light of enhancing the environment of doing business and attracting foreign investment. Accordingly, economic governance measures should be tailored to avoid negative perceptions by investors on the valuation of assets. This is essentially because a gloomy macroeconomic outlook motivates investors to divert their assets and capital to other countries. To further improve economic governance, governments of sampled countries need to be credible to retain investors as well as boost investors' confidence, promote private sector development and competition, limit political pressure that negatively affects the macroeconomic outlook and provide quality regulation.

Third, in relation to institutional governance, for investors (i.e. domestic and foreign) to retain capital in the sampled countries, such investors need to have confidence in domestic institutions in the short, medium and long terms. Such confidence starts when both the government and citizens respect prevailing institutions that govern interactions between them, 
especially as it pertains to upholding the rule of law, fighting corruption, protecting property rights and upholding better information accounting standards, inter alia.

The empirical contribution of this study is that to the best of our knowledge, we have focused on fighting capital flight through the capital flight trap, by modeling capital flight trap with interactive GMM. Future research can improve the existing literature by employing the technique in modeling the persistence of other macroeconomic variables with negative signals. Moreover, assessing whether the established linkages in the study withstand further empirical scrutiny when conditional distributions of governance variables are considered is also worthwhile. This recommendation is motivated by the fact that the established net effects are based on mean values of governance. In the light of the recommendation, above and below median levels of governance could provide other policy relevant insights. 


\section{Appendices}

\section{Appendix 1: Definitions of Variables}

\begin{tabular}{|c|c|c|c|}
\hline Variables & Signs & Definitions of Variables (Measurements) & Sources \\
\hline Capital Flight & & Ln of Capital Flight (constant of 2010) & $\begin{array}{l}\text { Ndikumana \& } \\
\text { Boyce (2012a) }\end{array}$ \\
\hline Political Stability & PolSta & $\begin{array}{l}\text { "Political stability/no violence (estimate): measured as the } \\
\text { perceptions of the likelihood that the government will be } \\
\text { destabilized or overthrown by unconstitutional and violent } \\
\text { means, including domestic violence and terrorism" }\end{array}$ & World Bank (WDI) \\
\hline $\begin{array}{l}\text { Voice \& } \\
\text { Accountability }\end{array}$ & $\mathrm{V} \& \mathrm{~A}$ & $\begin{array}{l}\text { "Voice and accountability (estimate): measures the extent to } \\
\text { which a country's citizens are able to participate in selecting } \\
\text { their government and to enjoy freedom of expression, freedom } \\
\text { of association and a free media". }\end{array}$ & World Bank (WDI) \\
\hline Political Governance & Polgov & $\begin{array}{l}\text { First Principal Component of Political Stability and Voice \& } \\
\text { Accountability. The process by which those in authority are } \\
\text { selected and replaced. }\end{array}$ & PCA \\
\hline $\begin{array}{l}\text { Government } \\
\text { Effectiveness }\end{array}$ & Gov. E & $\begin{array}{l}\text { "Government effectiveness (estimate): measures the quality of } \\
\text { public services, the quality and degree of independence from } \\
\text { political pressures of the civil service, the quality of policy } \\
\text { formulation and implementation, and the credibility of } \\
\text { governments' commitments to such policies". }\end{array}$ & World Bank (WDI) \\
\hline Regulation Quality & RQ & $\begin{array}{l}\text { "Regulation quality (estimate): measured as the ability of the } \\
\text { government to formulate and implement sound policies and } \\
\text { regulations that permit and promote private sector } \\
\text { development". }\end{array}$ & World Bank (WDI) \\
\hline $\begin{array}{l}\text { Economic } \\
\text { Governance }\end{array}$ & Ecogov & $\begin{array}{l}\text { "First Principal Component of Government Effectiveness and } \\
\text { Regulation Quality. The capacity of government to formulate } \\
\text { \& implement policies, and to deliver services". }\end{array}$ & PCA \\
\hline Rule of Law & RL & $\begin{array}{l}\text { "Rule of law (estimate): captures perceptions of the extent to } \\
\text { which agents have confidence in and abide by the rules of } \\
\text { society and in particular the quality of contract enforcement, } \\
\text { property rights, the police, the courts, as well as the likelihood } \\
\text { of crime and violence". }\end{array}$ & World Bank (WDI) \\
\hline Corruption-Control & $\mathrm{CC}$ & $\begin{array}{l}\text { "Control of corruption (estimate): captures perceptions of the } \\
\text { extent to which public power is exercised for private gain, } \\
\text { including both petty and grand forms of corruption, as well as } \\
\text { "capture' of the state by elites and private interests". }\end{array}$ & World Bank (WDI) \\
\hline $\begin{array}{l}\text { Institutional } \\
\text { Governance }\end{array}$ & Instgov & $\begin{array}{l}\text { First Principal Component of Rule of Law and Corruption- } \\
\text { Control. The respect for citizens and the state of institutions } \\
\text { that govern the interactions among them }\end{array}$ & PCA \\
\hline Trade Openness & Trade & Export plus Imports of Goods and Services (\% of GDP) & World Bank (WDI) \\
\hline GDP growth & GDPg & Gross Domestic Product (GDP) growth (annual \%) & World Bank (WDI) \\
\hline Inflation & Infl. & Consumer Price Index (annual \%) & World Bank (WDI) \\
\hline Foreign investment & FDI & Foreign Direct Investment inflows (\% of GDP) & World Bank (WDI) \\
\hline Public Investment & Pub.I & Gross Public Investment (\% of GDP) & World Bank (WDI) \\
\hline
\end{tabular}

WDI: World Bank Development Indicators. PCA: Principal Component Analysis. 
Appendix 2: Summary statistics (1996-2010)

\begin{tabular}{llllll}
\hline & Mean & SD & Minimum & Maximum & Observations \\
\cline { 2 - 5 } Capital flight (log) & 9.993 & 0.806 & 6.816 & 12.333 & 464 \\
Political Stability & -0.637 & 0.943 & -2.986 & 1.188 & 444 \\
Voice \& Accountability & -0.668 & 0.667 & -1.885 & 0.932 & 444 \\
Political Governance & -0.052 & 1.257 & -2.974 & 2.709 & 444 \\
Government Effectiveness & -0.640 & 0.578 & -1.974 & 0.876 & 443 \\
Regulation Quality & -0.631 & 0.562 & -2.412 & 0.791 & 444 \\
Economic Governance & 0.172 & 1.216 & -3.284 & 3.276 & 443 \\
Rule of Law & -0.694 & 0.613 & -2.207 & 0.773 & 444 \\
Control of Corruption & -0.571 & 0.579 & -2.057 & 1.249 & 443 \\
Institutional Governance & 0.049 & 1.313 & -3.139 & 3.676 & 443 \\
Trade Openness & 75.890 & 39.816 & 17.858 & 255.015 & 525 \\
GDP growth & 4.435 & 4.661 & -17.254 & 33.629 & 540 \\
Inflation & 74.917 & 1099.538 & -100.00 & 24411.03 & 508 \\
Foreign Direct Investment inflows & 3.994 & 5.935 & -8.629 & 40.157 & 405 \\
Public Investment & 7.217 & 4.143 & 0.000 & 25.007 & 477 \\
\hline
\end{tabular}

S.D: Standard Deviation.

Appendix 3: Correlation matrix (Uniform sample size: 248)

\begin{tabular}{|c|c|c|c|c|c|c|c|c|c|c|c|c|c|c|c|}
\hline \multicolumn{3}{|c|}{ Political governance } & \multicolumn{3}{|c|}{ Economic governance } & \multicolumn{3}{|c|}{ Institutional governance } & \multirow[b]{2}{*}{ Trade } & \multicolumn{3}{|c|}{ Control variables } & \multicolumn{3}{|c|}{ Capital } \\
\hline PS & VA & Polgov & $\mathrm{GE}$ & $\mathrm{RQ}$ & Ecogov & $\mathrm{CC}$ & RL & Instgov & & GDPg & Infl. & FDI & Pub.I & Flight & \\
\hline \multirow[t]{15}{*}{1.000} & 0.734 & 0.930 & 0.658 & 0.642 & 0.672 & 0.718 & 0.773 & 0.773 & 0.320 & -0.001 & -0.218 & 0.106 & 0.352 & -0.196 & PS \\
\hline & 1.000 & 0.932 & 0.761 & 0.739 & 0.775 & 0.738 & 0.773 & 0.783 & 0.067 & -0.018 & -0.153 & 0.049 & 0.215 & -0.024 & VA \\
\hline & & 1.000 & 0.762 & 0.742 & 0.777 & 0.782 & 0.830 & 0.836 & 0.207 & -0.010 & -0.199 & 0.083 & 0.304 & -0.118 & Polgov \\
\hline & & & 1.000 & 0.873 & 0.969 & 0.858 & 0.879 & 0.901 & 0.006 & 0.004 & -0.215 & -0.051 & 0.247 & 0.184 & $\mathrm{GE}$ \\
\hline & & & & 1.000 & 0.965 & 0.747 & 0.818 & 0.811 & -0.018 & -0.105 & -0.297 & -0.127 & 0.099 & 0.167 & RQ \\
\hline & & & & & 1.000 & 0.831 & 0.878 & 0.886 & -0.005 & -0.050 & -0.263 & -0.091 & 0.181 & 0.181 & Ecogov \\
\hline & & & & & & 1.000 & 0.855 & 0.966 & 0.153 & -0.049 & -0.215 & 0.008 & 0.296 & -0.040 & $\mathrm{CC}$ \\
\hline & & & & & & & 1.000 & 0.959 & 0.110 & -0.016 & -0.236 & 0.052 & 0.341 & 0.027 & RL \\
\hline & & & & & & & & 1.000 & 0.138 & -0.034 & -0.234 & 0.030 & 0.329 & -0.008 & Instgov \\
\hline & & & & & & & & & 1.000 & -0.051 & 0.127 & 0.358 & 0.299 & -0.253 & Trade \\
\hline & & & & & & & & & & 1.000 & 0.037 & 0.039 & 0.155 & 0.085 & GDPg \\
\hline & & & & & & & & & & & 1.000 & 0.185 & -0.003 & 0.209 & Infl. \\
\hline & & & & & & & & & & & & 1.000 & 0.202 & -0.169 & FDI \\
\hline & & & & & & & & & & & & & 1.000 & -0.257 & Pub. I \\
\hline & & & & & & & & & & & & & & 1.000 & Cap. Flight \\
\hline
\end{tabular}

PS: Political Stability/Non violence. VA: Voice \& Accountability. Polgov: Political Governance. GE: Government Effectiveness. RQ: Regulation Quality. Ecogov: Economic Governance. CC: Corruption-Control.RL: Rule of Law. Instgov: Institutional Governance. Trade: Trade Openness. GDPg: GDP growth. Infl: Inflation. FDI: Foreign Direct Investment inflows. Pub.I: Public Investment. Cap. Flight: Capital Flight.

\section{Compliance with Ethical Standards}

The authors are self-funded and have received no funding for this manuscript. The authors also have no conflict of interest.

This article does not contain any studies with human participants or animals performed by the authors. 


\section{References}

Ajide, K. B, \& Raheem, I. D., (2016a). "Institutions-FDI Nexus in ECOWAS Countries", Journal of African Business, 17(3), pp. 319-341.

Ajide, K. B, \& Raheem, I. D., (2016b). "The Institutional Quality Impact on Remittances in the ECOWAS Sub-Region", African Development Review, 28(4), pp. 462-481.

Andrés, R. A, \& Asongu, S. A., (2013). "Fighting Software Piracy: Which Governance Tools Matter in Africa?", Journal of Business Ethics, 118(3), pp. 667-682.

Andrés, R. A, Asongu, S. A., \& Amavilah, V. H., (2015). "The Impact of Formal Institutions on Knowledge Economy", Journal of the Knowledge Economy, 6(4), pp. 1034-1062.

Arellano, M., \& Bover, O., (1995). "Another look at the instrumental variable estimation of error-components models", Journal of Econometrics, 68(1), pp. 29-52.

Asongu, S. A., (2012). "Law and finance in Africa", Brussels Economic Review, 55(4), pp. 385-408.

Asongu, S. A., (2013, October). "Fighting African capital flight: timelines for the adoption of common policies", The Empirical Economics Letters,

http://www.eel.my100megs.com/volume-12-number-10.htm (Accessed: 09/08/2015).

Asongu, S. A., (2014a). "Fighting African Capital Flight: Empirics on Benchmarking Policy Harmonization", The European Journal of Comparative Economics, 11(1), pp. 93-122.

Asongu, S. A., (2014b). "Finance and Democracy in Africa". Institutions and Economies, 6(3), pp. 92- 118.

Asongu, S. A., (2015). "Rational Asymmetric Development, Piketty and the Spirit of Poverty in Africa". African Governance and Development Institute Working Paper No. 15/006, Yaoundé.

Asongu, S. A., (2016). "Determinants of Growth in Fast Developing Countries: Evidence from Bundling and Unbundling Institutions”, Politics \& Policy, 44(1), pp. 97-134.

Asongu, S. A., (2017a). "Assessing marginal, threshold, and net effects of financial globalisation on financial development in Africa", Journal of Multinational Financial Management, 40(June), pp. 103-114.

Asongu, S. A., (2017b). "The Effect of Reducing Information Asymmetry on Loan Price and Quantity in the African Banking Industry", Research in International Business and Finance, 41(October), pp. 185-197.

Asongu, S. A., (2019). "The persistence of global terrorism”, Territory, Politics \& Governance, DOI: 10.1080/21622671.2019.1675532. 
Asongu, S. A., \& Amankwah-Amoah, J., (2018). "Mitigating capital flight through military expenditure: Insight from 37 African countries", Research in International Business and Finance, 45(October), pp. 38-53.

Asongu, S. A., \& Biekpe, N., (2017). "ICT, information asymmetry and market power in African banking industry”, Research in International Business and Finance, 44(April), pp. 518-531.

Asongu, S. A., \& De Moor, L., (2017). "Financial globalisation dynamic thresholds for financial development: evidence from Africa", The European Journal of Development Research, 29(1), pp. 192-212.

Asongu, S. A., \& Kodila-Tedika, O., (2016). "Fighting African Conflicts and Crimes: Which Governance Tools Matter?” International Journal of Social Economics, 43(5), pp. 466-485.

Asongu, S. A., Nting, R. T., \& Osabuohien, E. S., (2019). "One Bad Turn Deserves Another: How Terrorism Sustains the Addiction to Capital Flight in Africa", Journal of Industry, Competition and Trade, 19(3), pp. 501-535.

Asongu, S. A., \& Nwachukwu, J., (2016a). "Revolution empirics: predicting the Arab Spring” Empirical Economics, 51(2), pp. 439-482.

Asongu, S. A, \& Nwachukwu, J. C., (2016b). "The Mobile Phone in the Diffusion of Knowledge for Institutional Quality in Sub Saharan Africa”, World Development, 86(October), pp. 133-147.

Asongu, S. A, \& Nwachukwu, J. C., (2016c). "Foreign aid and governance in Africa", International Review of Applied Economics, 30(1), pp. 69-88.

Asongu, S. A, \& Nwachukwu, J. C., (2016d). "Law, Politics and the Quality of Government in Africa”. Politics \& Policy, 44(5), pp. 916-944.

Asongu, S. A, \& Nwachukwu, J. C., (2017). "Fighting Capital Flight in Africa: Evidence from Bundling and Unbundling Governance", Journal of Industry, Competition and Trade, 17(3), pp. 305-323.

Asongu, S. A., \& Odhiambo, N. M., (2019a). "Challenges of Doing Business in Africa: A Systematic Review", Journal of African Business, 20(2), pp. 259-268.

Asongu, S. A., \& Odhiambo, N. M., (2019b). "Governance, Capital flight and Industrialisation in Africa", Journal of Economic Structures, 8(36), pp. 1-22.

Asongu, S. A., \& Odhiambo, N. M., (2020). "Enhancing Governance for Environmental Sustainability in Sub-Saharan Africa", Energy Exploration \& Exploitation; Forthcoming.

Ba, J., \& Ng S (2006). "Confidence intervals for diffusion index forecasts and inference for factor-augmented regression”, Econometrica, 74(4), pp. 1133-1150. 
Back, H., \& Hadenius, A., (2008). "Democracy and State Capacity: Exploring a J-Shaped Relationship”. Governance, 21(1), pp. 1-24.

Bai, J., (2003). "Inferential theory for factor models of large dimensions". Econometrica, 71 (1), pp.135-173.

Bai, J., (2009). "Panel data models with interactive fixed effects". Econometrica, 77(4), pp. 1229-1279.

Baliamoune-Lutz, M., \& Ndikumana, L., (2008). "Corruption and Growth: Exploring the Investment Channel”, University of Massachusetts - Amherst, Economics Department Working Paper Series. Paper No. 33

http://scholarworks.umass.edu/cgi/viewcontent.cgi?article=1022\&context=econ_workingpape r (Accessed: 02/07/2016).

Baltagi, B. H., (2008). "Forecasting with panel data", Journal of Forecasting, 27(2), pp. 153173.

Bartels, F. L., Alladina, S. N., and Lederer, S., (2009). "Foreign direct investment in subSaharan Africa: Motivating factors and policy issues". Journal of African Business, 10(2), pp. 141-162.

Beck, T., Demirgüç-Kunt, A., \& Levine, R., (2003), "Law and finance: why does legal origin matter?”, Journal of Comparative Economics, 31(4), pp. 653-675.

Boateng, A., Asongu, S. A., Akamavi, R., \&Tchamyou, V. S., (2018). "Information Asymmetry and Market Power in the African Banking Industry", Journal of Multinational Financial Management, 44(March), pp. 69-83.

Boyce, J. K., \& Ndikumana L. (2011). "Capital flight from sub-Saharan Africa: linkages with external borrowing and policy options", International Review of Applied Economics, 25(2), pp. 149-170.

Boyce, J. K., \& Ndikumana L. (2012a). "Capital Flight from Sub-Saharan African Countries: Updated Estimate, 1970-2010', Political Economy Research Institute, University of Massachusetts.

http://www.peri.umass.edu/fileadmin/pdf/ADP/SSAfrica capitalflight Oct23 2012.pdf (Accessed: 09/08/2015).

Boyce, J. K., \& Ndikumana L. (2012b). "Rich Presidents of Poor Nations: Capital Flight from Resource-Rich Countries in Africa', Political Economy Research Institute University of Massachusetts. http://concernedafricascholars.org/wp-content/uploads/2012/11/caploss01-ndiku-14th.pdf (Accessed: 09/08/2015).

Boyce, J. K., \& Ndikumana L., (2003). "Public Debt and Private Assets: Explaining Capital Flight from Sub-Saharan African Countries”, World Development, 31(1), pp. 107-130.

Boyce, J. K., \& Ndikumana, L. (1998). “Congo's odious debt: External borrowing and capital flight in Zaire", Development and Change, 29(2), pp. 195-217. 
Boyce, J. K., \& Ndikumana, L. (2001). "Is Africa a Net Creditor? New Estimate of Capital Flight from Severely Indebted Sub-Saharan African Countries, 1970-1996", Journal of Development,38(2), pp. 27-56.

Christensen, J. (2011). "The looting continues: Tax havens and corruption". Critical Perspectives on International Business, 7(2), pp.177-196.

Collier, P., Hoeffler, A. \& Pattillo, C., (2004). “Africa's Exodus: Capital Flight and the Brain Drain as Portfolio Decisions”. Journal of African Economies, 13(2), pp. 15-54.

Darley, W. K., (2012). "Increasing sub-Saharan Africa's share of foreign direct investment: Public policy challenges, strategies, and implications". Journal of African Business, pp. 13(1), 62-69.

Davies, V. (2008), "Post-war Capital Flight and Inflation”. Journal of Peace Research, 45(4),pp. 519-537.

Dewan, S., \& Ramaprasad, J., (2014). "Social media, traditional media and music sales", MIS Quarterly, 38(1), pp. 101-128.

Djankov, S., La Porta, R., Lopez-de-Silanes, F., \& Shleifer, A., (2003). “Courts”, Quaterly Journal of Economics, 118(2), pp. 453-517.

Efobi, U., \& Asongu, S. A., (2016). "Terrorism and Capital Flight from Africa", International Economics, 148 (December), pp. 81-94.

Fowowe, B., (2014). "Law and Finance Revisited: Evidence from African Countries", South African Journal of Economics, 82(2), pp.193-208.

Franco, A., Malhotra, N., \&Simonovits, G., (2014). "Publication Bias in the Social Sciences: Unlocking the File Drawer”, Science, 345(6203), pp. 1502-1505.

Gani, A., (2011). "Governance and Growth in Developing Countries", Journal of Economic Issues, 45(1), pp. 19-40.

Gankou, J-M., Bendoma, M., \& Sow, M. N., (2016). "The Institutional Environment and the Link between Capital Flows and Capital Flight in Cameroon", African Development Review, 28(S1), pp. 65-87.

GTI (2014). "Global Terrorism Index: Measuring and Understanding the Impact of Terrorism", Institute for Economics and Peace, pp. 2-90.

http://www.visionofhumanity.org/sites/default/files/Global\%20Terrorism\%20Index\%20Repor t\%202014_0.pdf (Accessed: 28/04/2015).

Greenaway-McGrevy, R., Han, C., \& Sul, D., (2012). "Asymptotic distribution of factor augmented estimators for panel regression". Journal of Econometrics, 169 (1), pp. 48-53. 
Kangoye, T., (2013). "Does Aid Unpredictability Weaken Governance? Evidence From Developing Countries", The Developing Economies, 51(2), pp. 121-144.

Keefer, P., (2007). "Clientelism, Credibility, and the Policy Choices of Young Democracies". American Journal of Political Science, 51(4), pp. 804-821.

Kelsey, D., \& le Roux, S., (2017). "Dragon Slaying with Ambiguity: Theory and Experiments", Journal of Public Economic Theory, 19(1), pp. 178-197.

Kelsey, D., \& le Roux, S., (2018). "Strategic Ambiguity and Decision-making: An Experimental Study”, Theory \& Decision, 84(3), pp 387-404.

Kou, G., Chao, X., Peng, Y., \& Alsaadi, F. E., (2019a). "Machine learning methods combined with financial systemic risk", Technological and Economic Development of Economy, DOI: https://doi.org/10.3846/tede.2019.8740

Kou, G., Yang, P., Xiao, F., Chen, Y., \& Alsaadi, F. E., (2019b). "Evaluation of feature selection methods for text classification with small datasets using multiple criteria decisionmaking methods", Applied Soft Computing, DOI:

https://doi.org/10.1016/j.asoc.2019.105836.

Kou, G., Ergu, D., Chen, Y., \& Lin, C., (2016). "Pairwise comparison matrix in multiple criteria decision making”, Technological and Economic Development of Economy, 22(5), pp. 738-765.

Kou, G., Lu, Y., Peng, Y., \& Shi, Y., (2012). "Evaluation of Classification Algorithms using MCDM and Rank Correlation", International Journal of Information Technology \& Decision Making, 11(1), pp. 197-225.

Kou, G., Peng, Y., \& Wang, G., (2014). "Evaluation of clustering algorithms for financial risk analysis using MCDM methods", Information Sciences, 275(August), pp. 1-12.

Kwaramba, M., Mahonye, N., \& Mandishara, L., (2016). "Capital Flight and Trade Misinvoicing in Zimbabwe”, African Development Review, 28(S1), pp. 50-64.

Jolliffe, I. T. (2002). Principal Component Analysis (2nd Ed.) New York: Springer.

Kaiser, H. F. (1974). “An index of factorial simplicity” Psychometrika, 39(1), pp. 31-36.

Kaufmann, D., Kraay, A \& Mastruzzi, M., (2010). "The worldwide governance indicators: Methodology and analytical Issues". World Bank Policy Research Working Paper No 5430, Washington.

La Porta, R., Lopez-de-Silanes, F., Shleifer, A., \& Vishny, R.W., (1998). "Law and finance”, Journal of Political Economy, 106(6), pp. 1113-1155.

La Porta, R., Lopez-de-Silanes, F., Shleifer, A., \& Vishny, R.W., (1999). "The quality of government”, Journal of Law, Economics and Organization, 15(1), pp. 222-279. 
Le, Q. V., \& Zak. P. J., (2006). "Political risk and capital flight". Journal of International Money and Finance, 25(2), pp. 308-329.

Lensink, R., Hermes, N., \& Murinde. V., (2000). 'Capital flight and political risk'. Journal of International Money and Finance, 19(1), pp. 73-92.

Li, G., Kou, G., \& Peng, Y., (2016). "A group decision making model for integrating heterogeneous information". IEEE Transactions on Systems, Man, and Cybernetics: Systems, DOI: http://dx.doi.org/10.1109/tsmc.2016.2627050

Li, T., Kou, G., Peng, Y., \& Shi, Y., (2014). "Classifying With Adaptive Hyper-Spheres: An Incremental Classifier Based on Competitive Learning", IEEE Transactions on Systems, Man, and Cybernetics: Systems, pp. 1-12. DOI: https://doi.org/10.1109/TSMC.2017.2761360

Love, I., \& Zicchino, L., (2006). "Financial Development and Dynamic Investment Behaviour: Evidence from Panel VAR" .The Quarterly Review of Economics and Finance, 46(2), pp. 190-210.

McKenzie C, R., \& McAleer M (1997). "On efficient estimation and correct inference in models with generated regressors: A general approach." Japanese Economic Review, 48(4), pp. 368-389.

Moulemvo, A., (2016). "Impact of Capital Flight on Public Social Expenditure in CongoBrazzaville", African Development Review, 28(S1), pp. 113-123.

Mpenya, A. H. T., Metseyem, C., \& Epo, B. N., (2016). "Natural Resources and Capital Flight in Cameroon", African Development Review, 28(S1), pp. 88-99.

Muazu, I., \& Alagidede, P., (2017). "Financial Development, Growth Volatility and Information Asymmetry in sub-Saharan Africa: Does Law Matter?", South African Journal of Economics, 84(4), pp. 570-588.

Muchai, D. N., \& Muchai, J., (2016). "Fiscal Policy and Capital Flight in Kenya", African Development Review, 28(S1), pp. 8-21.

Musila, J. W., \& Sigué, S. P., (2010). “Corruption and International Trade: An Empirical Investigation of African Countries”, World Economy, 33(1), pp.129-146.

Ndiaye, A. S., \& Siri, A., (2016). "Capital Flight from Burkina Faso: Drivers and Impact on Tax Revenue”, African Development Review, 28(S1), pp. 100-112.

Ndikumana, L., (2016). "Causes and Effects of Capital Flight from Africa: Lessons from Case Studies”, African Development Review, 28(S1), pp. 2-7.

Ndikumana, L., \& Boyce, J. K., (2011a), Africa's odious debts: How foreign loans and capital flight bled a continent. London: Zed Books.

Ndikumana, L., \& Boyce, J. K., (2011b). "New estimates of capital flight from sub-Saharan African countries: Linkages with external borrowing and policy options". International 
Review of Applied Economics, 25(2), pp. 149-170.

Ndikumana, L., Boyce, J. \& Ndiaye, A.S. (2015). "Capital Flight: Measurement and Drivers", in Ajayi, S. I. and L. Ndikumana (Eds), Capital Flight from Africa: Causes, Effects, and Policy Issues, Oxford: Oxford University Press, 15-54.

Ndikumana, L., \& Sarr, M., (2016). "Capital flight and foreign direct investment in Africa: An investigation of the role of natural resource endowment", WIDER Working Paper No. 2016/58, Helsinki.

Nyatepe-Coo, A.A., (1994). "Capital flight in low-income sub-Saharan Africa: The effects of political climate and macroeconomic policies". Scandinavian Journal of Development Alternatives, 13(4), pp. 59-69.

Oluwatobi, S., Efobi, U.R., Olurinola, O.I., Alege, P. (2015), "Innovation in Africa: Why Institutions Matter”, South African Journal of Economics, 83(3), pp. 390-410.

Onifade, S. T., Ay, A., Asongu, S. A., \& Bekun, F. V., (2020a). "Revisiting the trade and unemployment nexus: Empirical evidence from the Nigerian economy", Journal of Public Affairs, DOI: 10.1002/pa.2053.

Onifade, S. T., Çevik, S., Erdoğan, S., Asongu, S. A., \& Bekun, F. V., (2020b). “An empirical retrospect of the impacts of government expenditures on economic growth: new evidence from the Nigerian economy", Journal of Economic Structure, DOI: 10.1186/s40008-0200186-7.

Oxley L, \& McAleer, M., (1993). "Econometric issues in macroeconomic models with generated regressors.” Journal of Economic Surveys, 7(1), pp. 1-40.

Pagan, A., (1984). "Econometric issues in the analysis of regressions with generated regressors", International Economic Review, 25(1), pp. 221-247.

Pesaran, M. H., (2006). "Estimation and inference in large heterogeneous panels with a multifactor error structure”. Econometrica 74 (4), pp. 967-1012.

Ramiandrisoa, O. T., \& Rakotomanana, J. M., (2016). "Why Is There Capital Flight from Developing Countries? The Case of Madagascar", African Development Review, 28(S1), pp. 22-38.

Roodman, D., (2009a). "A Note on the Theme of Too Many Instruments", Oxford Bulletin of Economics and Statistics, 71(1), pp. 135-158.

Roodman, D., (2009b). "How to do xtabond2: An introduction to difference and system GMM in Stata", Stata Journal, 9(1), pp. 86-136.

Rosenberg, M. S., (2005). "The file-drawer problem revisited: a general weighted method for calculating fail-safe numbers in meta-analysis", Evolution, 59(2), pp. 464-468. 
Stock, J. H. \& M. W. Watson (2002). "Forecasting using principal components from a large number of predictors". Journal of the American Statistical Association, 97 (460), pp.11671179 .

Sung, H. E., (2004). "Democracy and political corruption: a cross-national comparison". Crime, Law and Social Change, 41(2004), pp. 179-194.

Tchamyou, V. S, (2017). "The Role of Knowledge Economy in African Business", Journal of the Knowledge Economy, 8(4), pp. 1189-1228.

Tchamyou, V. S., (2020a). "Financial Access, Governance and the Persistence of Inequality in Africa: Mechanisms and Policy instruments", African Governance and Development Institute, Yaoundé.

Tchamyou, V. S., (2020b). "Education, Lifelong learning, Inequality and Financial access: Evidence from African countries".Contemporary Social Science. DOI: 10.1080/21582041.2018.1433314.

Tchamyou, V. S., (2019).“The Role of Information Sharing in Modulating the Effect of Financial Access on Inequality".Journal of African Business, 20(3), pp. 317-338.

Tchamyou, V. S., \&Asongu, S. A., (2017). "Information Sharing and Financial Sector Development in Africa”, Journal of African Business, 18(7), pp. 24-49.

Tchamyou, V. S., Asongu, S. A., \& Nwachukwu, J. C., (2018). "Effects of asymmetric information on market timing in the mutual fund industry", International Journal of Managerial Finance, 14(5), pp.542-557.

Tchamyou, V.S., Erreygers, G., \& Cassimon, D., (2019a). "Inequality, ICT and Financial Access in Africa", Technological Forecasting and Social Change,139(February), pp. 169184.

Tchamyou, V. S., Asongu, S. A., \& Odhiambo, N. M., (2019b). "The Role of ICT in Modulating the Effect of Education and Lifelong Learning on Income Inequality and Economic Growth in Africa", African Development Review, 31(3), pp. 261-274.

Tuomi, K., (2011). "The role of the investment climate and tax incentives in the foreign direct investment decision: Evidence from South Africa". Journal of African Business, 12(1), pp. 133- 147.

Westerlund, J., \& Urbain, J-P., (2013a). "On the estimation and inference in factor-augmented panel regressions with correlated loadings”, Economic Letters, 119(3), pp. 247-250.

Westerlund, J., \& Urbain, J-P., (2013b). "On the implementation and use of factor-augmented regressions in panel data”, Journal of Asian Economics, 28(October), pp. 3-11.

Westerlund, J., \& Urbain, J-P., (2012). “Cross-sectional averages versus principal components", Maastricht University, RM/11/053, Maastricht. 
Weeks, J., (2012). "Macroeconomic impact of capital flows in Sub-Saharan African countries, 1980-2008”, Association of Concerned Africa Scholar Bulletin, 87, pp. 1-7.

Weeks, J., (2015). Macroeconomic impact of capital flows in Sub-Saharan Africa, in Ajayi, S.I., and Ndikumana, L., (Eds.), Capital Flight from Africa: Causes,Effects and Policy Issues. Oxford: Oxford University Press.

World Bank (2015). "World Development Indicators", World Bank Publications http://www.gopa.de/fr/news/world-bank-release-world-development-indicators-2015 (Accessed: 25/04/2015).

Yerrabati, S., \& Hawkes, D., (2015). "Economic Governance and Economic Growth in South and East Asia \& Pacific Region: Evidence from Systematic Literature Reviews and Metaanalysis". Advances in Economics and Business, 3(1), pp. 1 - 21.

Zhang, H., Kou, G., \& Peng, Y., (2019). "Soft consensus cost models for group decision making and economic interpretations", European Journal of Operational Research, 277(3), pp. 964-980. 